\title{
The effect of supplementary lysine on growth performance in the pig : comparison of industrial L-lysine $\mathrm{HCl}$ and sulfate
}

\author{
D. BOURDON, Y. HENRY \\ I.N.R.A., Station de Recherches sur l'Elevage des Porcs, \\ Saint-Gilles, 35590 L'Hermitage
}

\begin{abstract}
A growth trial was conducted on 120 growing-finishing pigs between 28 and $100 \mathrm{~kg}$ live weight in order to study the effect of supplementary industrial lysine on growth performance and carcass characteristics according to the form of L-lysine $(\mathrm{HCl}$ and sulfate) and the level of supplementation. Five treatments were compared with 12 Large White females and castrated males in each. The level of lysine in the basal diet containing maize, wheat, soyabean meal and maize gluten (treatment 1) was adjusted to 0.68 and $0.49 \mathrm{p}$. 100 within the live weight intervals 28 to $60 \mathrm{~kg}$ and 60 to $100 \mathrm{~kg}$, respectively; the protein level was maintained at $17 \mathrm{p} .100$ and the DE content was $3.3 \mathrm{Mcal} / \mathrm{kg}$. Supplementary additions of L-lysine in the pure form $(0.10$ or $0.20 \mathrm{p} .100)$ were made throughout the experiment either with L-lysine $\mathrm{HCl}$ containing 78.5 p. 100 pure lysine (treatments 2 and 3) or with L-lysine sulfate containing 42.7 p. 100 pure lysine (treatments 4 and 5). The pigs were fed according to a scale adjusted at a level close to appetite. The results were the following :
\end{abstract}

1) The average growth performance provided by L-lysine sulfate was equivalent to that obtained with L-lysine $\mathrm{HCl}$. During the whole experiment, the addition of $0.10 \mathrm{p} .100$ lysine allowed an improvement of the average daily gain (ADG) of 49 and $57 \mathrm{~g}$ with $\mathrm{HCl}$ and sulfate forms, respectively while feed conversion ratio (FCR) decreased by 0.25 in both cases.

2) Under the conditions of lysine deficiency a supplementary supply of 0.10 p. 100 of the limiting amino acid (lysine base) provided an average increase in ADG of $53 \mathrm{~g}$ over the entire period associated with 0.25 decrease in FCR. This corresponded to $18 \mathrm{~kg}$ feed saving between 28 and $100 \mathrm{~kg}$ live weight. The muscle content in the hot carcass (with head) increased by 1.2 point, while the fat percentage in the carcass (without head) was 1 point lower.

3) The castrated males like the females issued from a rapidly growing lean genotype, responded favourably to a supplementary lysine supply, although to a less extent up to a level exceeding 0.8 and $0.7 \mathrm{p}$. 100 within the weight intervals 28 to 60 and 60 to $100 \mathrm{~kg}$, respectively under the conditions of feed restriction at a level slightly below ad libitum feeding.

\section{Influence of ambient temperature and meal frequency on the efficiency of lysine supplementation}

\section{J. LOUGNON}

\author{
A.E.C. (Service Développement Alimentation Animale), 03600 Commentry
}

Two experiments were conducted to study the factors likely to affect the efficiency of free lysine supplementing a diet deficient in this amino acid.

Experiment A compared the performance of growing-finishing pigs (from 25 to $95 \mathrm{~kg}$ ) fed three different diets containing 16.5-15.0 or 13.5 p. 100 crude protein, but with the same lysine content $(0.80$ p. 100$)$. The last two feeds were supplemented with a new form 